\title{
Thyroid function and aging: gender-related differences
}

\author{
V M Corrêa da Costa, D G Moreira and D Rosenthal \\ Laboratório de Fisiologia Endócrina, Instituto de Biofísica Carlos Chagas Filho, Universidade Federal do Rio de Janeiro, 21949·900-Rio de Janeiro, \\ Brazil \\ (Requests for offprints should be addressed to V M Corrêa da Costa)
}

\begin{abstract}
The effects of aging on human or animal thyroid function are still not well defined. We evaluated some aspects of thyroid function during aging using an animal model (young and old Dutch-Miranda rats). In old rats of both genders, serum thyroxine (T4) decreased but serum thyrotrophin (TSH) remained unaltered, suggesting a disturbance in the pituitary-thyroid feedback mechanism during aging. Serum tri-iodothyronine (T3) only decreased in old males, possibly because female rats are almost twice as efficient in hepatic T4 to T3 deiodination. Thyroidal T4-5'-deiodinase activity did not change much during aging, although it decreased slightly in males. Thyroidal iodothyronine-deiodinase type I mRNA expression but not total thyroidal enzymatic activity were
\end{abstract}

higher in female than in male rats. Thus, ovarian/testicular hormones may modulate the expression and/or the activity of hepatic and thyroidal type I iodothyronine-deiodinase. Thyroperoxidase (TPO) and thyroglobulin (Tg) expression were higher in young male rats than in females. In males, TPO and Tg gene expression decreased with aging, suggesting that androgens might increase their expression. Our results showed that aging induces real changes in rat thyroid gland function and regulation, affecting at least pituitary, thyroid and liver functions. Furthermore, some of these changes were gender related, indicating that gonadal hormones may modulate thyroid gland function and regulation.

Journal of Endocrinology (2001) 171, 193-198

\section{Introduction}

Thyroid hormone formation involves iodide uptake by the follicular cell, its oxidation by thyroperoxidase (TPO) and incorporation into thyroglobulin (Tg). All steps leading to thyroid hormone synthesis, as well as $\mathrm{Tg}$ endocytosis and proteolysis, with the subsequent thyroid hormone secretion, are thyrotrophin (TSH) dependent. TSH production and secretion are stimulated by hypothalamic thyrotrophin-releasing hormone (TRH) and suppressed by thyroid hormones, in a classic negative feedback control system.

Serum thyroxine (T4) is entirely originated from the thyroid gland, while more than $80 \%$ of plasma triiodothyronine (T3) is produced by $5^{\prime}$-monodeiodination of $\mathrm{T} 4$, catalysed mainly by the selenocysteine-containing enzyme iodothyronine-deiodinase type I (DI-I), particularly in liver but also in kidney and other tissues (Berry et al. 1991). The T3 secreted by the thyroid gland can be partly derived from $\mathrm{T} 4$ monodeiodinated within the gland by a specific DI-I which is activated by pituitary TSH (Erickson et al. 1982). The type II 5'-deiodinase (DI-II) is also present in the thyroid gland (Salvatore et al. 1996), and can contribute to thyroidal T3 production, but in much smaller amounts.

Aging alters some aspects of hypothalamic-pituitarythyroid function. Some of these alterations seem to be gender related in humans (Samuels 1998) and in rats (Greeley et al. 1983). Hypothalamic TRH content is reduced in aged rats (Solomon 1991), but the effect of aging on thyrotroph responsivity to TRH is still controversial (Klug \& Adelman 1979, Greeley et al. 1983). Normal circulating levels of TSH have frequently been found in aged rats, in spite of low serum thyroid hormone levels (Klug \& Adelman 1979, Greeley et al. 1983, Donda \& Lemarchand-Béraud 1989).

We previously reported low T4 serum levels associated with normal serum levels of TSH and T3 in aged female rats (Corrêa da Costa \& Rosenthal 1996). Donda \& Lemarchand-Béraud (1989) reported low serum T4 and T3 with normal serum TSH in aged male rats, and related them to an increased pituitary $\mathrm{T} 3$ generation from $\mathrm{T} 4$. Our results in old female rats did not reproduce those found by Donda \& Lemarchand-Béraud (1989) in aged males. In fact, we found a significant decrease in the intra-pituitary $\mathrm{T} 3$ production from $\mathrm{T} 4$ in the old females (Corrêa da Costa \& Rosenthal 1996), suggesting that aging may affect thyroid function and regulation differently depending on gender, and thus be modulated by gonadal hormones.

In order to better evaluate pituitary-thyroid function during aging in both sexes, we studied the changes induced by aging in serum $\mathrm{T} 3, \mathrm{~T} 4$ and $\mathrm{TSH}$, in thyroid and hepatic T4-5'-deiodinase (T4-5'-DI) activity as well 
as in the mRNA expression of DI-I, TPO and $\mathrm{Tg}$ in female and male, young and old rats.

\section{Materials and Methods}

Animals and hormone measurements

The study protocol was approved by the Institutional Use of Animals in Research Committee, and the procedures used were in compliance with the International Guiding Principles for Biomedical Research Involving Animals, Council for International Organisations of Medical Sciences (Geneva, Switzerland), and the guiding principles for care and use of animals from the American Physiological Society.

Female and male Dutch-Miranda rats were kept from birth in a temperature-controlled $\left(22-25^{\circ} \mathrm{C}\right)$ animal room, with a $12 \mathrm{~h}$ light: $12 \mathrm{~h}$ darkness cycle, and received pelleted commercial chow (Paulínea, Sao Paulo, Brazil); iodine content $2 \mathrm{mg} / \mathrm{kg}$ ) and water available ad libitum. When aged 3-5 months (young) or 10-15 months (old) the animals were killed under ether. Blood was at once collected from the jugular vein. Thyroid gland and liver were rapidly removed, weighed, pooled and stored under liquid nitrogen for a maximum period of $48 \mathrm{~h}$. Sera were stored at $-20{ }^{\circ} \mathrm{C}$ until hormone measurements. Serum T4, T3 and TSH were determined by specific radioimmunoassays (RIA). Serum TSH was measured using a kit supplied by the National Hormone and Peptide Program, NIDDK (Bethesda, MD, USA) and expressed in terms of the preparation (RP-2) provided.

\section{T4-5'-DI activity assay}

DI activity was determined in the microsomal fraction obtained from $70 \mathrm{mg}$ hepatic or thyroid tissue (five to six pooled glands) after minor modifications of previously described methods (Kaplan \& Yaskoski 1980, Ishii et al. 1981, Boye \& Lauberg 1984, Corrêa da Costa \& Rosenthal 1996). The pooled thyroid glands and the hepatic tissue were homogenised in $50 \mathrm{mM}$ Tris- $\mathrm{HCl}$ buffer, $\mathrm{pH} 7 \cdot 4$, containing $250 \mathrm{mM}$ sucrose and $5 \mathrm{mM}$ dithiothreitol. The homogenates were centrifuged at $12000 \mathrm{~g}$ and $4{ }^{\circ} \mathrm{C}$ for $20 \mathrm{~min}$. The supernatant was centrifuged twice at $100000 \mathrm{~g}$ and $4{ }^{\circ} \mathrm{C}$ for $60 \mathrm{~min}$, and the washed pellet was taken up in sucrose-less homogenising buffer. Protein concentration was determined by the method of Bradford (1976). The microsomal fractions were diluted to a protein concentration of $20-50 \mu \mathrm{g} / 100 \mu \mathrm{l}$. The DI assay mixture contained $100 \mu \mathrm{l}$ microsomal fraction and $2 \mu \mathrm{M} \mathrm{T} 4$, in a final volume of $125 \mu \mathrm{l}$, and was incubated at $37^{\circ} \mathrm{C}$ for $20 \mathrm{~min}$ for the thyroid assay, and during $30 \mathrm{~min}$ for the hepatic assay. The reaction was stopped by the addition of $250 \mu \mathrm{l}$ ice-cold
95\% ethanol. The T3 formed was determined in the alcoholic extracts by an adapted and specific RIA and corrected for extraction efficiency. DI activity is expressed as pmol T3 formed/mg microsomal fraction protein (pmol T3/mg ptn).

\section{Northern blot analysis}

Total RNAs were extracted from five pooled thyroid glands (50-75 mg), unless otherwise indicated, using the QuickPrep Total RNA extraction kit (Pharmacia, Uppsala, Sweden). To determine mRNA expression for DI-I, TPO, Tg and cyclophilin (internal control), $50 \mu \mathrm{g}$ total RNA was electrophoresed through $1 \cdot 2 \%$ agarose gel containing $2 \cdot 2 \mathrm{M}$ formaldehyde, transferred overnight to a positively charged nylon membrane (Sigma, St Louis, MO, USA) with $20 \times \mathrm{SSC}$ ( $3 \mathrm{M}$ sodium chloride, $300 \mathrm{mM}$ sodium citrate), and cross-linked to the nylon membrane with a UV Multilinker (UV Stratalinker 1800, Stratagene). The blots were prehybridised at $42{ }^{\circ} \mathrm{C}$ in a hybridisation mix containing $50 \%$ formamide, $5 \times$ SSC, $10 \times$ Denhardt and $1 \%$ SDS for $2-4 \mathrm{~h}$, hybridised with the specific radiolabelled cDNA at $42^{\circ} \mathrm{C}$ for $16 \mathrm{~h}$, and then rinsed, at $42^{\circ} \mathrm{C}$, once in low stringency $(1 \times \mathrm{SSC}, 0.5 \%$ SDS) for $15 \mathrm{~min}$ and once under high stringency $(0 \cdot 1 \times$ SSC, $0.5 \%$ SDS $)$ for $15 \mathrm{~min}$ for the DI-I and TPO probes, and twice under high stringency for the Tg and cyclophilin probes. The blots were autoradiographed, at $-80^{\circ} \mathrm{C}$, for 7 days (DI-I and TPO probes) or for $48 \mathrm{~h}$ (Tg and cyclophilin probes) using Kodak X-OMAT AR film with an intensifying screen. The densitometry analysis was done with an Imaging Densitometer (Bio-Rad, Richmond, CA, USA).

The $2 \cdot 1 \mathrm{~kb}$ DI-I cDNA fragment was kindly provided by Drs M J Berry and P R Larsen (Boston, MA, USA), separated from the KS+ pBluescript vector by NotI and XhoI enzymatic digestion, and purified using the QIAEX II kit (Qiagen, Santa Clarita, CA, USA). The TPO cDNA fragment was linearised by XhoI digestion, and the $\mathrm{Tg}$ cDNA fragment was linearised by HindIII digestion; both were kindly provided by Dr R DiLauro (Naples, Italy). The cDNAs were radiolabelled with $\alpha\left[{ }^{32} \mathrm{P}\right] \mathrm{dCTP}$ using a random primer labelling system from GIBCO-BRL (New York, NY, USA).

\section{Statistical analysis}

Hormone measurements and DI activities are presented as means \pm S.E.M. Serum TSH values were analysed after logarithmic transformation. Two-way analysis of variance, and post-hoc Newman-Keuls test or Sheffe's multiple contrasts (Zar 1996) were used for statistical evaluation of data, using the SuperANOVA program (Abacus Concept, Berkeley, CA, USA). 
Table 1 Effect of aging on male and female rat serum levels of T4, T3 and TSH.

Values are means or means \pm S.E.M.

\begin{tabular}{|c|c|c|c|c|}
\hline & \multicolumn{2}{|l|}{ Males } & \multicolumn{2}{|l|}{ Females } \\
\hline & $3-5$ months & 10-15 months & $3-5$ months & 10-15 months \\
\hline TSH (ng/ml) & $\begin{array}{l}2 \cdot 01 \\
(1 \cdot 72 \pm 2 \cdot 34)\end{array}$ & $\begin{array}{l}1 \cdot 86 \\
(1 \cdot 76 \pm 1 \cdot 97)\end{array}$ & $\begin{array}{l}1 \cdot 42 \\
(1 \cdot 20 \pm 1 \cdot 68)\end{array}$ & $\begin{array}{l}1 \cdot 71 \\
(1 \cdot 54 \pm 1 \cdot 90)\end{array}$ \\
\hline T3 (ng/dl) & $31 \cdot 9 \pm 4 \cdot 4$ & $18 \cdot 2 \pm 3 \cdot 9^{*}$ & $41 \cdot 2 \pm 4 \cdot 2$ & $33 \cdot 9 \pm 3 \cdot 4$ \\
\hline $\mathrm{T} 4(\mu \mathrm{g} / \mathrm{dl})$ & $3 \cdot 84 \pm 0 \cdot 16$ & $2 \cdot 86 \pm 0 \cdot 22^{*}$ & $3 \cdot 53 \pm 0 \cdot 21$ & $2 \cdot 90 \pm 0 \cdot 17^{*}$ \\
\hline
\end{tabular}

TSH values were analysed after logarithmic transformation, (geometric mean and (mean \pm S.E.M. values)).

${ }^{*} P<0 \cdot 05$ or less compared with young animals.

\section{Results}

Serum T4 was markedly decreased in old rats of both genders, but serum TSH was unaffected. Serum T3 decreased only in aged males (Table 1).

Thyroidal mRNA levels for DI-I were unaffected by aging in males or in females, but females seemed to express more mRNA for DI-I in the thyroid than males, even when aged (Fig. 1).

On the other hand, we found no difference between the T4-5'-DI activity in thyroid glands of young or aged animals of both genders, although in aged male rats it was slightly lower than in aged females (Fig. $2 A$ ). The hepatic T4-5'-DI activity was significantly higher in females than

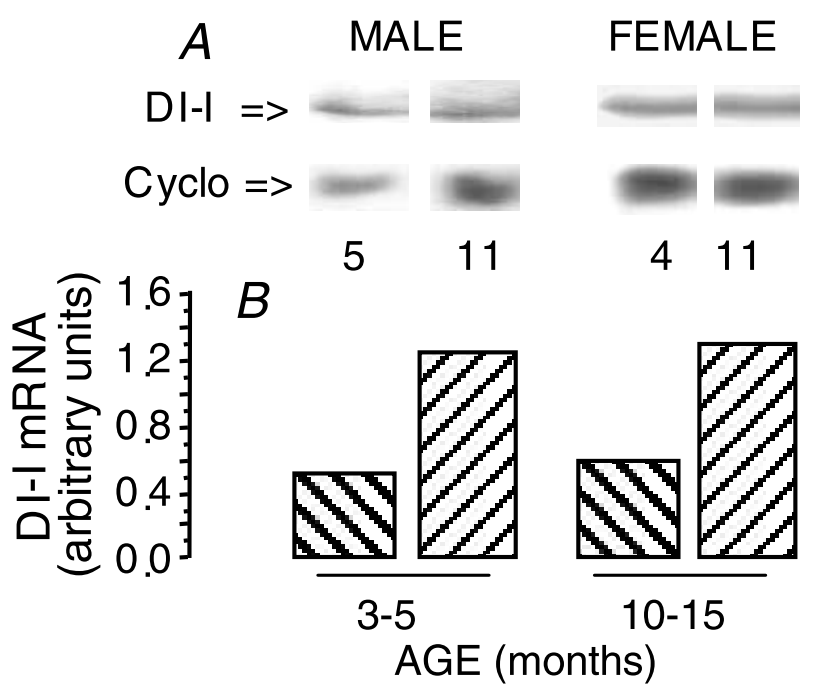

Figure 1 Thyroidal DI-I mRNA levels in young (3-5 months old) and old (10-15 months old) male and female rats. (A) A representative Northern blot autoradiograph (ages (in months) are shown below the blots; Cyclo=cyclophylin). (B) Densitometric determinations are normalised relative to cyclophylin mRNA; means of triplicate (male; left-hand bars) or duplicate (female; right-hand bars) assays in pools of five thyroid glands. in males, and decreased with aging in both genders, but the decrease was only statistically significant in females (Fig. 2B).

Thyroidal TPO mRNA and Tg mRNA levels were markedly greater in the young male rats than in the young females, but decreased with aging, while no change was detected in the old females (Figs 3 and 4).

\section{Discussion}

There are many theories about the processes that might be involved in aging. The endocrine system is often referred to as being affected, since aging alters the function of many endocrine glands, including the pituitary and thyroid glands (Morley 1995). In the present study, aging significantly decreased serum T4 in male and female rats, as previously reported (Klug \& Adelman 1979, Greeley et al. 1983, Donda \& Lemarchand-Béraud 1989, Corrêa da Costa \& Rosenthal 1996). Normally, decreased thyroid hormone serum levels should stimulate TSH secretion and result in increased TSH serum levels. A few reports of increased TSH in aging rats have indeed been presented (Pekary et al. 1983, Cónsole et al. 1995) but, in this and other studies (Klug \& Adelman 1979, Greeley et al. 1983, Donda \& Lemarchand-Béraud 1989, Corrêa da Costa \& Rosenthal 1996), no feedback response seems to have occurred and serum TSH remained unchanged in the old animals despite decreased serum T4. One might argue that in old females the TSH unresponsiveness to decreased T4 could be due to the unaltered T3 serum levels, but the same explanation would not be acceptable to explain the unaltered serum TSH in aged males, which had significant decreases of serum T4 and T3. These observations showed that, directly or through a decrease of TRH stimulus, the aged thyrotrophs are unable to respond efficiently to the decreased negative modulation by thyroid hormones.

Borges et al. (1998) reported that TSH release by unstimulated explants of aged male rat pituitaries was decreased. However, there was no difference between 

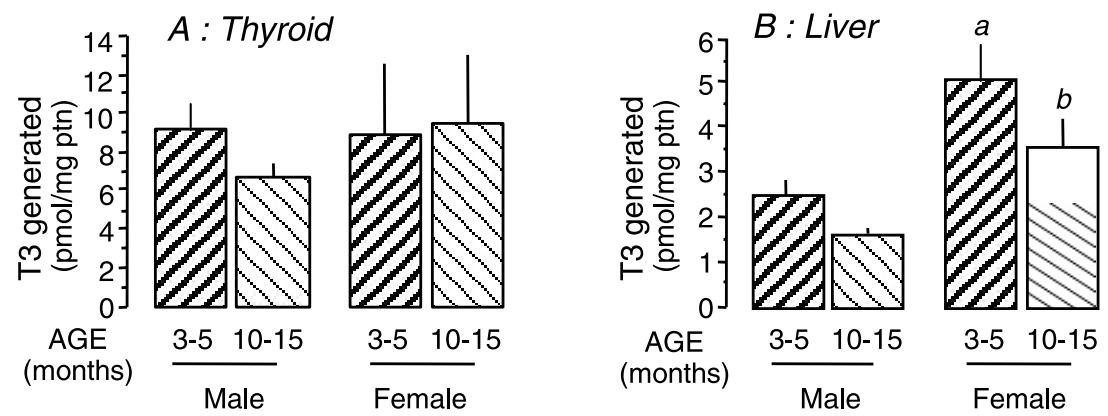

Figure 2 T4-5'-DI activity in young (3-5 months old) and old (10-15 months old) male and female rats. DI activity was determined by the T3 generated from T4 (see Materials and Methods). Results are presented as means \pm S.E.M. of at least $(A)$ three pools of five to six thyroid glands each or $(B)$ nine liver samples. ${ }^{a} P<0.05$ or less compared with young or old males; ${ }^{b} P<0.05$ or less compared with young females and young and old males.

TSH released by young or old TRH-stimulated rat pituitary explants. Neither basal nor TRH-stimulated TSH release differed between young and old female pituitary explants. Borges et al. (1998) suggest that pituitary responsiveness to TRH is maintained in old rats. Thus, the decrease in basal TSH secretion by the aged male rat pituitary would indicate a decrease of endogenous TRH, possibly related to diminished serum testosterone. Cizza et al. (1996) reported decreased hypothalamic TRH and pituitary TSH $\beta$ mRNA levels in old versus young male rats, but no difference in hypothalamic TRH mRNA between young and old females, although the circulating thyroid hormone levels were decreased in old rats of both genders. In their view, aging appears to be associated with central hypothyroidism in both genders, although the magnitude of the alteration is less in female than in male rats (Cizza et al. 1996). A previous study by the same investigators had already localised the age-related decrease in TRH mRNA in aged male rats to the hypothalamic paraventricular nucleus, the nucleus that controls TSH secretion (Cizza et al. 1992).

Our results also show that females, whether young or old, are more efficient in hepatic T3 generation from T4 than males, even considering the significant decrease in

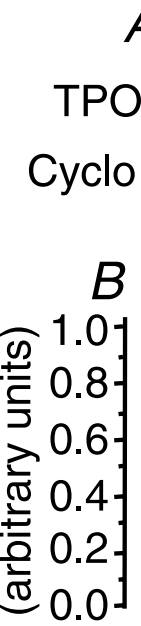

A MALE

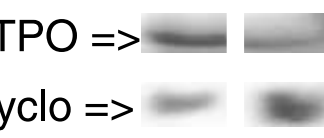

$5 \quad 11$

$B$

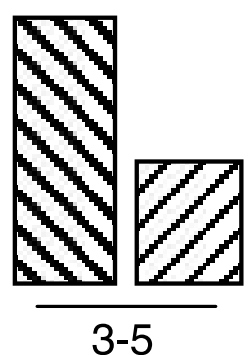

AGE (months)
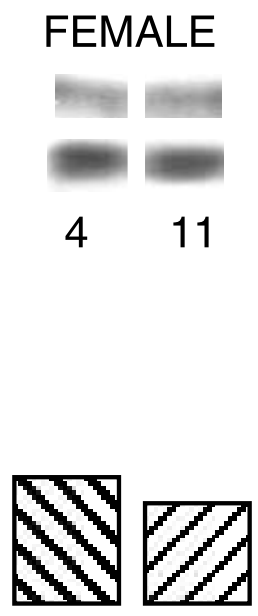

10-15

Figure 3 TPO mRNA levels in young (3-5 months old) and old (10-15 months old) male and female rats. (A) A representative Northern blot autoradiograph (ages (in months) are shown below the blots; Cyclo=cyclophylin). (B) Densitometric determinations are normalised relative to cyclophylin mRNA; means of triplicate (male; left-hand bars) or duplicate (female; right-hand bars) assays in pools of five thyroid glands.

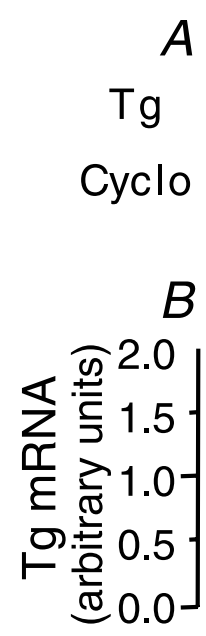

$A$

MALE

FEM ALE

$\operatorname{Tg}=>$

Cyclo $=>$ 5

11

$4 \quad 11$

$B$

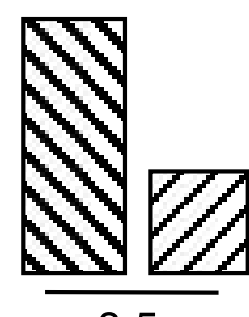

3-5

AGE (months)

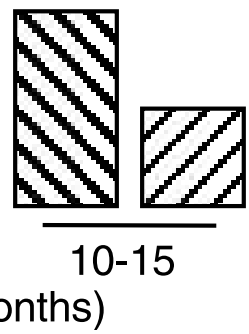

Figure $4 \mathrm{Tg}$ mRNA levels in young (3-5 months old) and old (10-15 months old) male and female rats. (A) A representative Northern blot autoradiograph (ages (in months) are shown below the blots; Cyclo=cyclophylin). (B) Densitometric determinations are normalised relative to cyclophylin mRNA; means of triplicate (male; left-hand bars) or duplicate (female; right-hand bars) assays in pools of five thyroid glands. 
hepatic T4-5'-DI activity detected in the aged females. The difference between hepatic DI activity in males and females may well be the reason for the normal T3 serum levels of aged females, and may be involved in the somewhat higher T3 serum levels present in the young females.

A preferential T3 release from the thyroid gland has been suggested to occur in aged animals of both genders (Pekary et al. 1983), but our data do not reinforce this. In fact, we found no change in thyroidal DI activity in aged females, even when very old (26 months, data not shown), and a slight, non-significant decrease in aged males. Furthermore, no significant differences in thyroidal DI activity were detected between males and females. Notwithstanding, the DI-I mRNA levels were higher in the female thyroid glands than in males. These differences suggest some gonadal hormone modulation on either thyroidal DI-I expression or total thyroidal DI activity. A stimulating effect of oestrogens on DI expression would agree with the greater hepatic DI activity in females and the unchanged DI-I mRNA in the old female thyroids, since the aging murine ovary decreases progesterone production but maintains oestrogen release for some time (Woodman 1997). This hypothesis also agrees with the findings of Lisbôa et al. (1997), who reported young adult male rats to have lower hepatic, pituitary and thyroidal DI activity than females. On the other hand, since the murine thyroid also expresses DI-II (Bates et al. 1999), we cannot disregard the possibility that in males the type II DI isoform might have a greater contribution to the $\mathrm{T} 3$ formed from $\mathrm{T} 4$ than in females.

TPO mRNA levels are decreased by about $50 \%$ in the aged male rats as compared with the young males, and are similar to those of young or old females. The difference between TPO mRNA in young males and in old males or females suggests a stimulatory effect of androgens on TPO expression. Thus, the marked decrease of TPO mRNA could be attributed to a decreased testosterone production by the aging murine testis (Woodman 1997, Wang et al. 1999, Gruenewald et al. 2000) although the timing and/or degree of the decline may differ between rat strains (Pekary et al. 1989, Wang et al. 1999, Lu et al. 2000). The Tg mRNA levels are also greater in the thyroids of young males than in the thyroids of females. In the old males (11-15 months) the Tg mRNA decreases by about 35\%, but by 26 months of age (data not shown) the Tg mRNA levels decrease by about $50 \%$, and become very similar to those found in young and old females.

In female rats, TPO mRNA and Tg mRNA levels are not affected by aging and are lower than in young males. An androgen-stimulatory effect could explain this difference, and the slightly higher serum TSH in the young male could also contribute to it, but these cannot be the only factors involved. Despite a lower TPO and Tg mRNA expression, the young female thyroid maintains serum T4 levels equal to those produced by the young male. Furthermore, in the presence of unchanged TSH serum levels, with no detectable changes in TPO and Tg mRNA expression, the aged female thyroid seems to be as unable to maintain normal $\mathrm{T} 4$ secretion as is the male gland. Thus, the aged murine thyroid becomes less responsive to circulating $\mathrm{TSH}$.

One possible explanation for this unresponsiveness of the aged thyroid to TSH was given by Studer et al. (1978) and Gerber et al. (1987). These authors suggest that a gradual failure of endocytosis in response to normal TSH stimulation would occur in the aging thyroid. At first, $\mathrm{Tg}$ exocytosis and iodination would be unaffected, resulting in gradual distension of the follicular lumen which would impair the normal apical membrane function.

Thus, our results suggest that aging, affecting at least the pituitary, thyroid and liver, induces real changes in the rat thyroid gland function and regulation. Furthermore, some of these changes are gender related, indicating that gonadal hormones may modulate thyroid gland function and regulation, but further studies are necessary before we are able to understand the mechanisms involved.

\section{Acknowledgements}

We would like to thank Dr Roberto DiLauro for kindly providing TPO and Tg cDNAs and Dr Marla J Berry and Dr Paul Reed Larsen for kindly providing DI-I cDNA. We also thank Mr Advaldo N Bezerra, Ms Norma L A Faria and Mr Wagner N Bezerra for excellent technical assistance. This research was supported in part by Financiadora de Estudos e Projetos, Brazil; Conselho de Ensino para Graduados, Universidade Federal do Rio de Janeiro and Conselho Nacional de Desenvolvimento Científico e Tecnológico, Brazil.

\section{References}

Bates JM, St Germain DL \& Galton VA 1999 Expression profiles of the three iodothyronine deiodinases, D1, D2 and D3 in the developing rat. Endocrinology 40 844-850.

Berry MJ, Banu L \& Larsen PR 1991 Type I iodothyronine deiodinase is a selenocysteine containing enzyme. Nature 349 438-440.

Borges PP, Curty FH, Pazos-Moura CC \& Moura EG 1998 Effect of testosterone propionate treatment on thyrotrophin secretion of young and old rats in vitro. Life Sciences 62 2035-2043.

Boye N \& Lauberg P 1984 Deiodination of T4 to T3 and rT3 by microsomes from normal human thyroid tissue. Molecular and Cellular Endocrinology 37 295-299.

Bradford MM 1976 A rapid and sensitive method for the quantification of microgram quantities of proteins utilizing the protein-dye binding. Analytical Biochemistry 72 248-254.

Cizza G, Brady LS, Calogero AE, Bagdy G, Lynn AB, Kling MA, Blackman MR \& Chrousos GF 1992 Central hypothyroidism is associated with advanced age in male Fisher 344/N rats: in vivo and in vitro studies. Endocrinology 131 2672-2680.

Cizza G, Brady LS, Esclapes M, Blackman MR, Gold PW \& Chrousos GP 1996 Age and gender influence basal and stressmodulated hypothalamic-pituitary-thyroidal function in Fisher 34/N rats. Neuroendocrinology 64 440-448. 
Cónsole GM, Gómez Dumm CLA \& Goya RG 1995 Immunohistochemical and radioimmunological assessment of thyrotrophs in the pituitary of ageing rats. Acta Anatomica 152 $28-32$.

Corrêa da Costa VM \& Rosenthal D 1996 Effect of ageing on thyroidal and pituitary T4 $5^{\prime}$ deiodinase activity in female rats. Life Sciences 59 1515-1520.

Donda A \& Lemarchand-Béraud T 1989 Ageing alters the activity of $5^{\prime}$ deiodinase in the adenohypophysis, thyroid gland and liver of male rats. Endocrinology 124 1305-1309.

Erickson VJ Cavalieri RR \& Rosenberg LL 1982 Thyroxine 5' deiodinase of rat thyroid, but not of liver, is dependent on thyrotropin. Endocrinology 111 434-440.

Gerber H, Peter HJ \& Studer H 1987 Age-related failure of endocytosis may be the pathogenetic mechanism responsible for 'cold' follicles formation in the ageing mouse thyroid gland. Endocrinology 120 1758-1764.

Greeley GH, Lipton MA Jr \& Kizer JS 1983 Serum thyroxine, triiodothyronine, TSH levels and TSH release after TRH in ageing male and female rats. Endocrine Research Communications 9 169-177.

Gruenewald DA, Nasi MA, Marck BT \& Matsumoto AM 2000 Age-related decrease in hypothalamic gonadotropin-releasing hormone $(\mathrm{GnRH})$ gene expression, but not pituitary responsiveness to $\mathrm{GnRH}$, in male Brown Norway rat. Journal of Andrology 21 $72-84$.

Ishii H, Inada M, Tanaka K, Mashio Y, Naik K, Nishikawa M \& Imura H 1981 Triiodothyronine generation from thyroxine in human thyroid: enhanced conversion in Graves thyroid tissue. Journal of Clinical Endocrinology and Metabolism 52 1211-1217.

Kaplan MM \& Yaskoski KA 1980 Phenolic and tyrosyl ring deiodination of iodothyronine in rat brain homogenates. Journal of Clinical Investigation 66 551-562.

Klug TL \& Adelman RC 1979 Altered hypothalamic-pituitary regulation of thyrotropin in male rats during ageing. Endocrinology 104 1136-1142.

Lisbôa PC, Curty FH, Moreira RM \& Pazos-Moura CC 1997 Effects of estradiol benzoate on $5^{\prime}$-iodothyronine deiodinase activities in female rat anterior pituitary gland, liver and thyroid gland. Brazilian Journal of Medical and Biological Research 30 1479-1484.
Lu CC, Tsai EJ, Chien EJ, Tsai CL \& Wang PS 2000 Age-related differences in the secretion of calcitonin in male rats. Metabolism 49 253-258

Morley JE 1995 Hormones, ageing and endocrine disorders in the elderly. In Endocrinology and Metabolism, edn 3, pp 1813-1836. Eds P Felig, JD Baxter \& LA Frohman. New York: McGraw-Hill Inc.

Pekary AE, Hershman JM, Sugawara M, Gieschen KI, Sogol PB, Reed AW, Pardridge WM \& Walfish PG 1983 Preferential release of triiodothyronine an intrathyroidal adaptation to reduced serum thyroxine in ageing rats. Journal of Gerontology 38 653-659.

Pekary AE, Knoble M \& Garcia N 1989 Thyrotropin-releasing hormone (TRH)-Gly conversion to TRH in rat ventral prostate is inhibited by castration and ageing. Endocrinology 125 679-685.

Salvatore D, Bartha T, Harney JW \& Larsen PR 1996 Type 2 iodothyronine deiodinase is highly expressed in human thyroid. Journal of Clinical Investigation 98 962-968.

Samuels MH 1998 Subclinical thyroid disease in the elderly. Thyroid $\mathbf{8}$ 803-813.

Solomon DH 1991 Effect of ageing on thyroid hormone metabolism. In Thyroid Hormone Metabolism Regulation and Clinical Implications, pp 267-292. Ed. S-Y Wu. Boston, USA: Blackwell Scientific Publications.

Studer H, Forster R, Conti A, Kohler H, Haeberli A \& Engler H 1978 Transformation of normal follicles into thyrotropin-refractory 'cold' follicles in the ageing mouse thyroid gland. Endocrinology 102 1576-1586.

Wang C, Hikim APS, Lue YH, Leung A, Baravarian S \& Swerdloff RS 1999 Reproductive ageing in the Brown Norway rat is characterized by accelerated germ cell apoptosis and is not altered by luteinizing hormone replacement. Journal of Andrology 20 509-518.

Woodman DD 1997 Laboratory Animal Endocrinology, pp 129-471. Chichester, West Sussex: John Wiley \& Sons.

Zar JH 1996 Biostatistical Analysis, pp 179-232. Upper Saddle River, NJ: Prentice-Hall International.

Received 8 March 2001

Accepted 11 June 2001 